Article

\title{
Avoidance as Inter-Religious Competence? Samaritans and Their Religious "Others" in Nablus, Palestine
}

\author{
Julia Droeber ${ }^{(D)}$ \\ Department of Islamic Pedagogy/Theology, University of Education Ludwigsburg, \\ 71634 Ludwigsburg, Germany; droeber@ph-ludwigsburg.de
}

Received: 30 November 2019; Accepted: 26 January 2020; Published: 5 February 2020

check for updates

\begin{abstract}
In this paper, I take issue with the theory and practice of inter-religious competence, based on a case-study of the Samaritans of Nablus. I take as a starting point the contemporary observation that inter-religious relations in Nablus are relatively peaceful, which in most models of inter-religious competence would be considered a product of successfully acquired and implemented inter-religious competences. A second observation, that runs against the grain of all models of inter-religious competence, is that Samaritans do not seem to discuss religious issues in public at all. I try to show that this strategy of avoidance is largely the result of historical experiences, which made "walking between the raindrops" seem the most successful way to maintain social peace. Furthermore, I attempt to demonstrate that the strategy of avoidance is one applied in public, but not in private discourses, which, in turn, I identify as a second strategy of inter-religious competence found in the Nablus context but not in pedagogical models. A third aspect, not mentioned in theoretical models of inter-religious competences, is the political context, which, in the case of Nablus, is marked by a strong discursive emphasis on local and national identity—against an external "enemy" — that overrides any religious boundaries.
\end{abstract}

Keywords: Inter-religious competence; Samaritans; Nablus

\section{Introduction}

In summer 2019, my family and I went to visit the museum in Kiryat Luza, the settlement of the Samaritan community on the outskirts of Nablus, West Bank. This museum, established in 2010 in cooperation with the Palestinian Authority to replace the much smaller Samaritan museum a few yards away, houses an exhibition of artefacts, charts, and displays on Samaritan history, beliefs, and practices. We arrived late in the afternoon, outside the opening hours, and only through personal acquaintances of my husband, a local Nabulsi, were we able to call the guide for an extra tour of the museum. Towards the end of the half-hour tour I asked him about the relations of the different religious communities in Nablus and how Samaritans learn about Islam and Muslims about Samaritanism. The guide - not a Samaritan himself, but of Jewish-Muslim extraction and a resident of Kiryat Luza for the past 10 years-looked conspiratorially at me and my husband (who is Greek Orthodox) and said: "Samaritans do not talk about religion for fear of conflicts (biseer fi touch)!"

This vignette summarises the main point and the main problem of this article. Religion, it appears, is not a subject Samaritans talk about in public settings. Despite-or because of - this, the "building" of inter-religious relations in Nablus seems a relatively stable one. The main question I am pursuing in this paper is, how Samaritans (and Christians and Muslims, for that matter) in Nablus come to develop a measure of inter-religious competence that enables them to deal, and coexist peacefully with their non-Samaritan (Muslim and Christian) neighbours in Nablus in day-to-day life. For this purpose, I am also re-examining pedagogical models of inter-religious competence in the light of this case study. 
The data, upon which the exploration of this question is based, was gathered over the course of 10 years, beginning with my first fieldwork stay in Nablus in 2009, over a 6-year residence in Nablus and yearly visits in the summer months since 2015. It consists largely of participant observation on various occasions, on which members of the different religious communities were in the same location—so-called "cross-cutting situations" (Überschneidungssituationen, Willems 2011, p. 13) or "critical incidents" (Willems 2011, p. 78). On some occasions, I held semi-formal interviews with members of the different religious communities. Not being an historian, I gleaned historical aspects of inter-religious relations and competences from secondary sources that deal with Nablus society, particularly where Samaritans, Christians, and Muslims are explicitly mentioned. The data is limited to the section of the Samaritan community resident in Kiryat Luza, near Nablus. I have not been able to visit the community living in Holon, Israel, mainly due to visa restrictions. I am aware of the fact that the circumstances in and of the Holon community may be quite different from those of the Nablus community and that, therefore, the development of inter-religious competences may differ between the two communities.

Before disentangling the question of inter-religious competences in the contemporary Nablus context, I shall first briefly outline the scholarly debate about the development of inter-religious competences. This theoretical background will offer some guidelines for the assessment of both the level of inter-religious competences evident in the Nablus context and the processes of developing them. Obviously, I am not suggesting that inter-religious competences can be measured with a yardstick; yet, the theoretical models provide us with the landmarks and clues necessary for an evaluation thereof.

In a further step, I will mine selected publications that provide historical information on inter-religious relations in the Nablus context for hints on consistencies and changes in the formation of inter-religious competences over the course of time.

This shall finally lead us to a discussion of the current state of affairs. How do inter-religious competences play out in the twenty-first century, when the political, social, and economic contexts differ quite markedly from past centuries? As an aside, this may lead us to question current educational models of inter-religious competence development. However, what do I mean by inter-religious competence and why do we need it?

\section{Learning to Deal with Difficult Encounters}

In past centuries-before the age of instant communication, instant travel, instant coffee and instant everything else-most individuals grew up and lived in relatively homogeneous communities, be that from a religious, economic, ethnic, or class perspective. Of course, there have always been differences within communities both past and present, and larger societies or political entities have always been very diverse, yet, most individuals lived their day-to-day life in small, relatively homogeneous groups and rarely moved beyond them. The dynamics of globalisation have changed this, so that even in the small German village that my family currently lives in, children have first encounters with other cultures, languages, and religions already in kindergarten. In other words, inter-religious and inter-cultural competences are essential in today's world if some sort of societal stability is to be maintained.

This brings us to the heart of inter-religious competence. Even though Kaufhold (2006, p. 21) claims that it has remained unclear, what competence actually means in different academic disciplines, and though the debate has a long history in educational studies (see Klieme and Hartig 2007), I shall, for the purpose of this paper, refer back to one of the earliest definitions provided by Weinert (2001): competence describes the abilities and capabilities required to solve problems. The "problems" in the given context are, of course, of an inter-religious nature. Willems (2011, p. 13) has adapted this definition to "inter-religious competences" and understands them as "competences that are necessary 
in order for people to master situations of inter-religious cross-cutting, thus, for them to understand what happens in such situations and to be able to act (appropriately) within them" (translation mine) ${ }^{1}$.

When it comes to inter-religious learning, Willems (2011, p. 114) discerned a consensus among most educationists: inter-religious learning contains the clarification of one's own position, the acquisition of religious basic knowledge, gaining hermeneutic abilities, a change of attitude, and the concrete dealing with members of different religions. Most models of inter-religious competence and learning, however, seem to focus on the first three of these aspects, while the last two, particularly the personal encounter with members of different religious communities, is largely being neglected. The so-called "Berlin model" of religious competence described by Willems (2011, p. 127) proposes two partial or sub-competences that need developing: interpretative and participatory competence; yet, it is mainly the former that seems to taken into consideration in further elaborations. This focus on cognitive aspects goes back mainly to practical considerations: as Willems (2011, p. 171f) explains, cognitive and oral aspects of inter-religious competence are easier to quantify, whereas qualitative research, while generally to be preferred, turns out to be too time consuming. For these reasons, the embodied dimension of inter-religious competence is usually not taken into further consideration.

In fact, as Willems (2011, p. 176) has noted, a model of development of inter-religious competences is still lacking. Schweitzer et al. (2017, p. 15) also point to the fact that the discussion about inter-religious competence remains "determined almost completely by theoretical models" and that empirical studies are still missing. Therefore, they emphasise that "we must not automatically assume that the aims of teaching linked to inter-religious competence are in fact reached" (ibid.). ${ }^{2}$

Many of these models are based on confessional and denominationally segregated religious education in schools, as is the norm in most German schools, for instance. Other forms of religious education would be so-called "denominationally cooperative" religious education, where catholic and protestant children are, at certain intervals, taught together (Kuld et al. 2009), or "religious education for all", where children of all kinds of religious background and none are taught in the same classrooms (Hecker 2008). Even though these models allow for dialogue and inter-religious communication in situ, there are obviously "limits and restrictions, which must be discussed and, wherever possible, be transgressed in the future (Kuld et al. 2009, p. 208). These Problems include the fact that, so far, we "lack a detailed didactic for denominationally cooperative RE" (ibid.) and that, according to Hecker (2008, p. 122) study, many participants complained about "pretence dialogues" 3 despite a relatively high level of dialogical competence (Hecker 2008, p. 122). In other words, formal educational settings often appear little suited for the development of inter-religious competences.

Based on these considerations, I understand inter-religious competence first and foremost as behaviour, as embodied knowledge and the ability to act appropriately in (challenging) situations of inter-religious encounters (see Droeber 2018). This understanding differs quite markedly from other concepts of (inter-religious) competence with their strong cognitive tendencies. These models of inter-religious competence focus mainly on "knowledge", "understanding", and "learning". The practical, embodied reference to a specific situation is generally mentioned only in passing. I will argue later on instead, that the embodied aspect of inter-religious competence is central to the ability to act in multireligious contexts. Elsewhere (Droeber 2018), I have argued that Bourdieu's concepts of dispositions and habitus may help us develop a new model of inter-religious competence that has bodily skills at its heart. This would also necessarily mean that the learning of inter-religious competences does not only, perhaps not even mainly, take place in formal educational settings, but

1 Original: „Kompetenzen, die notwendig sind, damit Personen interreligiöse Überschneidungssituationen bewältigen können, damit sie also verstehen, was in solchen Situationen geschieht, und damit sie in ihnen handlungsfähig sind“.

2 In their empirical study in colleges, the aim of religious change of perspective and change of religious attitudes was, in fact, not achieved (Schweitzer et al. 2017, p. 134).

3 A "pretence dialogue" is a dialogue", which "serves as a pretext to attack the position of the interlocuter or to impose one's own position onto the other" (ibid.). 
in everyday life. As we will see later, the data on which this article is based supports precisely this premise.

Both Bourdieu (2001) and models of inter-religious competence that take participatory elements into account assume that inter-religious learning takes place in situations, in which the habitus or old ways of doing things become "irritated" (Bourdieu) or "perturbed" (Willems). These are situations in which, in Bourdieu's parlance, habitus and social field are in discord and in which this discord cannot be easily circumvented. Then, certain dispositions can no longer be maintained, resulting in changes of habitus or bodily dispositions (Bourdieu 2001, p. 209). A discussion of the precise processes of transformation triggered in such situations is beyond the scope of this paper. Suffice it to note that it is in such situations of inter-religious overlap, cross-cutting, perturbance, and irritation that inter-religious competences become literally embodied. It is in such encounters that-to use Bourdieu's words-a new "sense of the game" is developing in individuals, leading to an increasingly successful, skilful, and smooth participation in that "game", which is a multi-religious society (cp. Pille 2002, p. 37).

A similar perspective is offered by Willems (2011, p. 76f) in his conceptualisation of situations of inter-religious overlap, which he considers to be a basic element of inter-religious competence. Instead of irritations he speaks of "perturbations", meaning challenges that one encounters and that influence one's perception of reality (Willems 2011, p. 67). On a cultural level, this means that cultural change does not happen unconditionally or haphazardly, but as a further development of existing cultural structures, in order to reach a new viable model and equilibrium in the face of perturbations (ibid.). This further development happens through accommodation, i.e., when coping with everyday challenges through the tried and trusted cultural mechanisms is no longer possible (as opposed to assimilation, in which case the existing mechanisms suffice for dealing with the challenges (ibid.)). A contemporary example of accommodation in the Samaritan context would be the break with the strict endogamy rule that did not allow Samaritans to marry outside their religious community. Assimilation may be seen in the contemporary efforts described later to explain Samaritan religion to a Muslim audience in terms very similar to Islamic terminology. Willems (2011, p. 78, referring to Heringer 2007, p. 218-21; Thomas $1993,2005)$ calls these kinds of challenges, which cannot be dealt with through assimilation-and in some cases not even through accommodation- "critical incidents". In the historical outline that follows, many of the violent clashes, uprisings, or massacres may be described as outcomes of such "critical incidents", when assimilation had become impossible and accommodation led to the emergence of new habits or views. Applied to situations of inter-religious overlap, critical incidents, therefore, describe situations in which those involved interact in accordance with different cultural or religious schemes of interpretation and communication, and in which they are sooner or later surprised because the actions of their partner of interaction no longer make sense against the background of one's own schemes (ibid.; translation mine) $)^{4}$. Bernlocher (2013, p. 311) equally emphasises the significance of intercultural-inter-religious spaces of cross-cutting as well as the fact that processes of inter-religious learning are, to a strong degree, determined by extra-theological factors ${ }^{5}$. Following on from these considerations, we may-and this is the essential point for this article-assume that inter-religious (and other) competences are being developed, re-formed, and altered mainly in practical situations of encounter rather than by acquiring theoretical knowledge in formal educational settings. They emerge in situations that involve and challenge the whole person, "body and soul".

Assuming that such situations emerge mainly in day-to-day life, I shall now examine what clues there are for Samaritans' accommodation and assimilation in cross-cutting situations in past centuries. How did they relate to members of other religious communities in their locality, mainly

4 Original: "Situationen, in denen die Beteiligten jeweils in Übereinstimmung mit unterschiedlichen kulturellen bzw. religiösen Deutungs- und Kommunikationsmustern interagieren und früher oder später überrascht sind, weil die Handlung des Interaktionspartners vor dem Hintergrund der eigenen Muster keinen ,Sinn' mehr macht".

5 Original: "zu einem hohen Grad von außertheologischen Faktoren bestimmt wird" (emphasis in the original). 
Muslims, Christians, and Jews? And what kind of inter-religious competence emerged from these historical experiences?

\section{Past Models of Coexistence}

The main problem we are facing in any discussion of inter-religious relations in past centuries is that of sources. Except for perhaps particularly outstanding events-in positive or negative terms-religious affiliation in everyday encounters between individuals or groups is hardly ever mentioned in historical sources on Nablus or Palestine. One has to dig very deep and also look in perhaps unusual places to find suitable information. Not being an historian, I have had to rely on others who have done that kind of work. It would have been desirable to use original Samaritan or Muslim sources in order to provide a nuanced picture of historical relations, taking into account diverging authorships, readerships, intentions, and biases. Yet, this is not the main focus of this paper. The picture that appears to emerge from the secondary sources that have used Samaritan original sources (e.g., Pummer 2016) and original Muslim sources (e.g., Ayash 2003) is that the history of inter-religious relations in Nablus (and perhaps Palestine as a whole) has known considerable ups and downs. We find alternating periods of "harmony" and "strife" throughout the centuries. What is striking is that especially the "downs" are very often conveniently "forgotten" in contemporary public discourses on inter-religious relations in the Nablus context. Some Samaritans themselves claim that they "coexist with all sides on good terms, in a region more commonly associated with conflict" (https://www.israelite-samaritans.com/medal/), or, like Ya'qub al-Kahin (president of the Samaritan Legend Association, see later), that "members of the [Samaritan] community have always, from the time of the forefathers, been eager to cherish and deepen the relations between all monotheistic religions" (http://www.al-bayader.org/2018/02/150176/). Non-Samaritans often argue that the three religions (Samaritans, Muslims, Christians) hold dear a "shared way of life (as opposed to mere coexistence) as [their] ancestors had lived and always wanted" (http://www.tmfm.net/article/65376). The mayor of Nablus, Sameeh Tubailah, said in 2019 that a shared way of life in Nablus is "one of the most important values in the city, where Muslims, Christians, and Samaritans have been living side by side for long centuries" (ibid.). We would, however, be mistaken if we took the contents of this public discourse as the only expression of past experiences. As I will show later on, the "downs" do feature in contemporary practices of inter-religious encounters. What are key experiences of past centuries that have left their traces on contemporary inter-religious relations in Nablus?

I begin this historical outline with the fourth century CE, when Christianity became state religion of the Roman Empire and, therefore, Christianity a significant factor in inter-religious relations in the region. However, religious struggles were evident even before that era, when, under the government of Hadrianus (117-38 CE), the Romans built a Jupiter temple on Mount Gerizim to replace the Samaritan place of worship there (Ayash, Hitti 1958, p. 346, and Dabbagh 1947-1964, p. 102, all cited in Ayash 2003, p. 22). Under the Byzantine Empire, the enmity between Jews (including Samaritans) and Christians (Byzantines) became more pronounced, which had its effects on inter-religious relations in Nablus. As a consequence of Roman pressure on and discrimination of Jews, and possibly triggered by rumours about a transfer of the remains of Aaron's sons and grandsons, much revered by the Samaritans (http://www.christusrex.org/www1/ofm/mad/discussion/035discuss.html), Samaritans in Nablus killed Christians in the city, which, in turn, angered Emperor Zenon (Ayash 2003, p. 22). He evicted them from Mount Gerizim and built a church of the "Virgin Mary" on the location of the Samaritan Temple, surrounding it with a wall (Ayash 2003, p. 22).

In the sixth century CE, Emperor Justinian (527-65) issued several discriminatory laws against non-Christian religious groups, including the Samaritans. (Pummer 2016, p. 137). This led the Samaritans into an uprising in $529 \mathrm{CE}$, during which they killed many Jews and Christians, priests and the patriarch, burning churches and other buildings (Pummer 2016, p. 139f.). The Roman district governor oppressed the revolt leaving in its wake large parts of the city of Nablus and the surrounding villages destroyed and many of their inhabitants killed (including around 20,000 
Samaritans; Pummer 2016). Priests were killed and a fortress built around the Church of the Virgin Mary on Mount Gerizim (Ibn al-'Tbri 1958:86; quoted in Ayash 2003, p. 22). Justinian's rule and legislation are generally said to have been very cruel towards non-Christians, his policies and laws deepening the rift between Jews and Christians, and declaring the former (including Samaritans) "unbelievers" (Rabello 1997).

After a brief interlude of a Sassanian occupation of Palestine under Chosrou Parviz (590-628 CE) at the beginning of the 7th century $\mathrm{CE}$, during which many Christian churches and monasteries were destroyed (Ayash 2003, p. 24), the fourth of the religious "forces" that concern us here, entered the historical stage: Muslims. In 636 CE, Muslims first entered Nablus. Some sources report that Samaritans fled the city towards the east into exile (Journal of Nablus Municipality, p. 18; quoted in Ayash 2003, p. 24). Arabic sources report that Nablus, like other cities of the region, were peacefully conquered by Muslims, without fighting. 'Amr ibn al-As, the commander of the Muslim armies, is reported to have granted the inhabitants of Nablus safety of their lives, savings, and houses in return for paying the jizya (per capita taxation levied on non-Muslims under Muslim rule). Thus, Nablus was spared fighting (Kalbuna 1992, p. 32ff). It is unclear on which side the Samaritans were in the era of the Muslim conquests: some sources claim that they sided with the Byzantines, others that they fought with Muslims against the Byzantines (Pummer 2016, p. 142f.).

Indeed, it appears that Samaritans fared relatively well under the first Muslim caliphs. Muslim and Samaritan sources, admittedly written at later points and with hindsight, report relatively peaceful relations (Pummer 2016, p. 146). The population of Nablus remained diverse, including Arabs and Persians, Muslims, Christians, Samaritans, and Jews. With the advent of the Abbasid caliphate (750-1250 CE), however, circumstances changed for the worse for the Samaritans in Nablus. Particularly under the Abbasid governor of Palestine Abd al-Wahhab b. Ibrahim Abu Shindy in the days of al-Mansur's caliphate (754-775 CE) the situation worsened considerably. The governor destroyed Zeno's tomb on Mount Gerizim, upon which Samaritans attacked the church on the same site and killed the monks (Ayash 2003, p. 25). The governor is also said to have increased taxes and fines on the Samaritan community (Pummer 2016, p. 146). As a consequence, many Samaritans fled into exile or converted to Islam. After the death of Harun ar-Rashid (786-809 CE), a conflict erupted between his sons about his succession, in the course of which many Samaritan cities and villages were destroyed (Ayash 2003). After the death of one of his sons, al-Amin, Muslims of Nablus felt encouraged to kill the governor of Nablus, as they felt he had become too close to the Samaritans, leading to civil unrest with much killing and fighting in the city (ibid.). Ayash (ibid.) calls this unrest "fitna", indicating civil war on religious grounds. Eventually, peace was restored and Samaritans were permitted to live and worship on Mount Gerizim (ibid.).

Under al-Mu'tasim (governed 833-42 CE), Muslim extremist (Kharijites) entered Nablus and burnt Samaritan temples. These riots were quelled, yet the Samaritans suffered severely from the taxes imposed on them as their land had become crown land and illnesses and agricultural calamities had taken their toll (Pummer 2016, p. 147). Many converted during this period in order to avoid hunger (Pummer 2016, p. 148). The centuries of Abbasid rule, were, therefore, marked by ups and downs for the Samaritans: some governors of Nablus were more benevolent towards them than others. Samaritans in different regions fared differently well in the same period because they were governed by different governors (Pummer 2016, p. 148). We may assume that the situation of the Samaritans, also in their everyday dealings with non-Samaritans, was crucially influenced by the attitude of those in power, particularly on the local level. Whenever a governor showed benevolence towards the Samaritans, we may assume that everyday relationships were also relatively peaceful.

The next religious group that forced itself onto the region was again of a Christian background in the shape of the Crusaders. Some historians mention that the Crusaders oppressed the Samaritans, expelled them from Nablus, and dispersed them in the country (Nimr 1961, p. 46f.). Crusader sources hardly ever mention the Samaritans. The first time they are hinted at is in the description of the conquest of Jerusalem, when "a nation from the mountains of Samaria came with presents, welcoming 
them (the Crusaders), and inviting them to seize their country (Journal of Nablus Municipality, p. 19; quoted in Ayash 2003, p. 26). King Godfrey of Jerusalem built a fortress on Mount Gerizim, and after that it is said that Nablus descended into chaos and oppression (Arif 1964, p. 18f). Others say that the period of Crusader rule was mainly peaceful for the Samaritans (Pummer 2016, p. 151). However, Nablus was not spared to conflict between the (Christian) Crusaders and the mainly Muslim local rulers. In 1113 CE, Muslims re-conquered Nablus and destroyed it. In 1137 CE, the ruler of Damascus took Nablus, slaughtered almost all its inhabitants and took 500 Samaritans as prisoners to Damascus. A Samaritan from Akko is said to have redeemed them and they went to Gaza (Ayash 2003, p. 26). When Saladin went to war with the Crusaders, Samaritans apparently helped him to free Nablus by showing his army an unguarded entrance to the city. His response was, so the legend goes, that he wrote a recommendation letter for the Samaritans to give to all the governors that came after him. This is how the benevolence of the governors towards them is explained by 'Azmi Naji Khadr, Samaritan priest (ibid.). Historical sources do not mention such an event. What is mentioned, is that Saladin entered Nablus in 1184 CE and destroyed the city. It then remained in Muslim hands until 1242 CE, when Crusaders returned to burn and kill.

Muslims loyal to Saladin, coming from Egypt, took the city in 1244 CE, before Mongols under Hulagu invaded Nablus in 1259 CE, again to destroy and kill. Samaritan sources report that the Samaritans of the city were among the victims and that they left for Damascus to join the Samaritan community there, and only very few of them returned to Nablus (Hitti 1958, p. 208; quoted in Ayash 2003, p. 26). The Mongol invasion was a relatively short, albeit violent, interval in the history of Nablus, as in $1260 \mathrm{CE}$, the Mamluks of Egypt, another Muslim dynasty took control of the city, defeating both Mongols and the remaining Crusaders. As a consequence, Christians were evicted from the city in 1261 CE, taken to Damascus, and their churches destroyed (Ayash 2003, p. 27). Similarly, the Samaritans had their "Temple of Jacob's mourning" (kanees huzn Ya'qoob) destroyed and fled to Damascus and Egypt. It is reported that the situation of the people worsened considerably in Nablus during those years (ibid.).

It is during this and the following period of Ottoman rule that the number of Samaritans dwindled considerably, down to probably around 1000 individuals in Nablus in the 12th century (Journal of Nablus Municipality, p. 21f; quoted in Ayash 2003, p. 27; Pummer 2016, p. 188). It is also during that time that the conversions by force became increasingly an issue. While Samaritan sources report forced conversions and discrimination as a major reason for the receding numbers, Muslim writers generally reject this idea, claiming that the Islamic conquests stand out by the good treatment of the new subjects by the Muslim rulers, particularly the "People of the Book", which usually include the Samaritans (Journal of Nablus Municipality, p. 23; quoted in Ayash 2003, p. 28).

Ottoman rule (1516-1918 CE) seems to have been a generally difficult period for the Samaritans. In 1538 CE, a large part of the Samaritans of Damascus, together with their High Priest and his son, returned to Nablus (Ayash 2003, p. 29). Many Samaritans were employed in government positions and with local ruling families, offering them opportunities to better themselves and their coreligionists, yet, at the same time, providing cause for envy and concern among many Muslims (Pummer 2016, p. 155ff.). The 17th century CE was apparently a difficult era, when Samaritans were oppressed by Muslim local rulers (Pummer 2016, p. 159). Under Mahmood I (1730-54 CE), the Samaritans were able to purchase a piece of land on Mount Gerizim for their religious rituals. Between 1785 and 1810 CE, it was, however, forbidden for them to worship there. In 1841 CE, under Ibrahim Pasha, Muslims killed many Samaritans, claiming that they were not People of the Book, a question that resurfaced regularly (Ayash 2003, p. 29). As a result, the Samaritans addressed themselves to the French King and to the British government. The latter provided financial assistance and promised protection by the British consul in Jerusalem (Ayash 2003, p. 30). While many Samaritans benefited from employment with local Arab families, this also entangled them in local rivalries and conflicts. It is said that only in the second half of the 19th century CE, when the local ruler was of Turkish origin rather than from a local Arab family, did the situation of the Samaritans improve in terms of security. As a consequence, 
they lost, however, their employment opportunities with local Arab families, so that their economic situation worsened (Pummer 2016, p. 164).

The 20th century saw the split of the Samaritan community into two groups, one in Holon and one in Nablus, initially for economic reasons. The split led to divergent experiences in the two communities, particularly after the creation of the state of Israel in 1948. While the two groups have been able to remain in close contact, at times interrupted for political reasons, such as under Jordanian rule over the West Bank, they have lived and continue to live their day-to-day lives in divergent socio-cultural environments. The violent conflicts that have been marking the area for almost a century, may, in Samaritan eyes, seem a continuation of the conflicts they have experienced in previous centuries, albeit with different players, and the difference being that they themselves are perhaps less directly involved than in the past This historical and contemporary experience has been lucidly described by Samaritans as "walking between the raindrops". I have described the contemporary "sitting between the chairs", particularly the situation after the Oslo Accords of 1993, elsewhere (Droeber 2014), as has Ireton (2003). What emerges from these analyses is a scenario of constant negotiating with those in power and the majority population. Although there are divergent reports about the event, the gradual evacuation of the Samaritan quarter in the Old City of Nablus in the 1980s is often linked to discrimination against the Samaritan population by the Palestinian leadership (Schur 1989, p. 131f.). Kiryat Luza, the settlement on Mount Gerizim, where they relocated, was built with Israeli support, yet could not guarantee a peaceful life for the Samaritans, as the events of the second intifada show, when Samaritans suffered from Israeli sanctions as did the rest of the population of Nablus (Ireton 2003). Both Palestinian and Israeli leaderships promised protection for the Samaritans, promises that were often broken. In other words, the Samaritans' situation in the 20th and 21st centuries continues to be insecure, albeit less marked by the direct violence experienced in the past. The period after the second intifada has meant relative peace and stability for the Samaritan community in Nablus. Yet, the lesson obviously learned from the past is that this stability will probably not last forever. As I will show below, current efforts to maintain this stability may be motivated by a fear by the minorities (Christians and Samaritans) of a future worsening of the situation. A major strategy used by the Samaritans to preserve this current level of relative peace is, as I will also explain in a moment, is to avoid discussing religious issues with non-Samaritans for fear of discrimination from the majority. Let me now turn to the link between the historical experiences outlined above and contemporary inter-religious competences.

\section{Collective Memory, Habitus and Inter-Religious Competence}

Following Bourdieu's concept of diposition and habitus, I assume that the past experiences described here have become part and parcel of Samaritans' collective memory, identity, and habitus. Even though individual Samaritans living today have not personally experienced the ups and downs of inter-religious relations outlined above, they are most likely raised in this spirit. ${ }^{6}$ A detailed discussion of the concept of "collective memory" would go beyond the scope of this paper; suffice it to note that, in contrast to the recording of history as, ideally, a comprehensive, accurate, and unbiased portrayal of past events, collective memory consists of a shared pool of memories, knowledge and information of a social group that represents a single, often biased perspective on past events. Perhaps the best and most concise summary of this collective memory is the phrase "walking between the raindrops" used frequently by Samaritans (e.g., Tsedaka 2008). Most often, this phrase is used to describe more recent developments after the foundation of the State of Israel in 1948, and especially after the Samaritan community separated into two geographical locations. I would, however, argue that this interpretation of the

6 For further assessing the Samaritan collective memory, it may seem useful to take the lacunae in Samaritan historiography into account, e.g. 5-6th century Samaritan rebellions that are not mentioned in Samaritan chronicles. It may indicate a similar anamnesis like the "forgetting" of other past struggles in contemporary discourse on inter-religious relations. I do, however, assume that contemporary Samaritans do not rely on Samaritan sources only for the formation of their historical knowledge or collective memory. 
contemporary situation is not a new idea, but rather a reflection of past experiences that have become entrenched in Samaritan collective memory and, following Bourdieu, embodied in the communities' individual members. Already in past centuries, as has become obvious above, Samaritans have learned to "walk between the raindrops" of various kinds of political regimes, attitudes, and policies. The overarching aim of ensuring the community's survival had and has to be played against political necessities and interests of others.

Applying these insights to the pedagogical models of the development of inter-religious competence, it becomes evident that Samaritans as a community and as individuals have, over the past centuries, if not millennia, experienced countless religious "cross-cutting situations", perturbations, or irritations, as they are variedly called. The religious disposition or habitus they have developed as a result of these encounters is part and parcel of their inter-religious competence today. If Bourdieu (1993, p. 128) is correct, then this disposition-being familiar with the rules of the game of "walking between the raindrops" - is something individual Samaritans are being socialised into through a "silent pedagogy", which is able, according to Bourdieu, to teach an entire cosmology, ethics, metaphysics, and politics through inconspicuous warnings such as "Keep straight!" or "Do not take the knife into your left hand!" and which bring to the fore basic principles of the culturally arbitrary through seemingly insignificant details of posture, behaviour or bodily and verbal manners, and which thus evade consciousness and explanation. In an inter-religious context, such "seemingly insignificant details of behaviour" would refer, for instance, to telling children what is "'aib" (shameful) in a Muslim majority society or to hide religious symbols in public. It may also refer to the switching of languages that becomes automatized: Arabic in public, (classical) Hebrew in private in the Nablus setting.

The resulting "competence" is supposed to express itself in the successful dealing with and solving of problems ensuing from contemporary inter-religious encounters. The most successful strategy learned from past encounters seems to be to "walk between the raindrops", i.e., to try to avoid frictions with other communities. In this spirit, inter-religious relations in contemporary Nablus are being constructed. Generally speaking, we can indeed call inter-religious "living together" in Nablus relatively successful. Keeping in mind that the pedagogical models of competence do so far not include any ideas, let alone tools, of measuring "success" in the acquisition of inter-religious competence, we may look at the general "climate" in Nablus to garner an indication of the levels of success of inter-religious competence. This general "climate" of inter-religious relations is over and over again described as largely harmonious by all of the religious communities involved, apart from few exceptions. As I have pointed out earlier, particularly on public occasions, Samaritans, Christians, and Muslims emphasise not only that contemporary relations are friendly, but also that they have always been that way. The historical sketches outlined above provide ample evidence that the latter confirmation is not based on historical fact, but are rather an interpretation of history, probably stemming from contemporary necessity. In other words, it appears that all parties involved have a keen (political) interest to portray inter-religious living-together in Nablus as "successful". Not only on a discursive level, but also in practice, there appears to be little evidence of gross discrimination of one religious group against another or others or even stark physical violence. Elsewhere (Droeber 2014) I have shown that members of the two religious minority groups in Nablus-Christians and Samaritans-often experience low-level discrimination and mobbing by Muslim individuals, but there are no openly discriminatory policies in place that refer to religious affiliation.

One differentiation that is nowhere indicated in the pedagogical models of inter-religious competence is that between the private and public sphere, even though this is crucial also for the educational sphere. Just as we may try to "measure" inter-religious competence inside and outside the classroom, i.e., in the learning environment and in "real life", we have to examine inter-religious competence in the public sphere and in private. I have previously used Scott (1990) concept of "hidden transcripts" to analyse the difference I have observed between what is said about other religious groups in public in Nablus and what members of a religious group speak between themselves about others (Droeber 2014). What has emerged from this is that we find two different, at times opposing, discourses 
about religious "Others". The "public transcript", as Scott calls it, is one of inter-religious harmony and understanding, while the "hidden transcripts" are marked by an emphasis on difference, stereotyping, gossiping, and victimisation. The existence of such parallel discourses may, of course, be interpreted as a failure of endeavours to foster "true" shared-life and mutual understanding between religious communities or as a lack of "true" inter-religious competence. This would, however, place the focus of competence again merely on the cognitive and communicative levels and assume that everything that is said and done in public is solely make-believe and playacting. I would, however, based on theories of performance (cp Austin 1962), argue that not only does the public transcript contribute to the nature of inter-religious relations, but also that this differentiation of discourses may constitute a complex strategy of inter-religious competence.

In summary, I would argue that the historical experiences of the Samaritans with the respective non-Samaritan rulers and the broader population-whose behaviour towards "Others" was always sanctioned according to the political regime in place at a certain time-have helped develop certain inter-religious strategies that make peaceful relations and coexistence possible. One of the lessons learned was obviously that "to walk between the raindrops" was a potentially successful strategy to reach the aim of peaceful relations with non-Samaritans. ${ }^{7}$ The strategy is obviously not one of cutting all ties with the Muslim majority in Nablus and thus avoiding any risk of conflict, which would have been possible after attaining Israeli citizenship and moving to Kiryat Luza. Most Samaritans are in daily contact with non-Samaritan Nabulsis and have often actively been seeking this contact, as I will show in the next section.

Another strategy developed from past and more recent experiences appears to be that it is essential for the Samaritans (as well as the Christians as the other religious minority group in Nablus) to keep emphasising the similarities with the majority, be they theological, social or political. This would be the content of the public transcript. The existence of a hidden transcript that does not have the same contents may also indicate lessons learned from the past, i.e., that to openly speak about differences between religions or their adherents does not serve the purpose of granting peaceful social relations. It is in this sense that past experiences help Samaritans "to master situations of inter-religious cross-cutting, thus, for them to understand what happens in such situations and to be able to act (appropriately) within them" (Willems 2011, p. 13).

In the final section of this paper, I would like to briefly look at the contemporary situation of inter-religious relations in Nablus. I examine, on the one hand, the public transcript that is marked by endeavours to actively foster good relations rather than by strategies of avoidance, and, on the other hand, I discuss the role played by the current political constellation in ensuring peaceful relations.

\section{Other Factors Ensuring "The Peace”}

As I have already indicated several times, the public transcript in Nablus is marked by an emphasis on "brotherliness" and "harmony" between religious minority and majority groups. I have already quoted from media reports and other sources to that effect. At this point, I would like to focus particularly on one Samaritan group that has been intervening in the public transcript on behalf of the Samaritan community in Nablus (not in Holon) for the past ten years. "The Samaritan Legend Association" (jam'iyyat al-astura as-samiriyya, SLA) was established and is being run mainly by the younger generation of Samaritans. They have organised countless activities and initiatives in order to raise awareness among non-Samaritans about their existence, their history, beliefs, and practices. Recently (October 2019), they set up an internet site (www.samaritans-la.com), which is exclusively in English and obviously aimed at an international audience. The heading of the "about" section of the

7 It may be argued that Samaritans have a history of not discussing religious matters with non-Samaritans, as historical sources seem to indicate. This, however, has not helped avoid the violent conflicts of past centuries, so that the strategy may only be successful under certain political conditions. 
website reads "The Samaritan Legend Association spreading the story of the Good Samaritan", thus clearly indicating that the addressees of the site are English-speaking Christians, whose only association of "Samaritan" is assumed to be with the "Good Samaritan" of the New Testament. Interesting as this website is, it is of no further import here, since I am concerned with the local Nabulsi population. Older than the website is the Association's Facebook site, on which they announce and document their and others' activities. Here the addressees are clearly local, as the site is almost exclusively in Arabic, as are comments, announcements and reports. They have more than 1000 followers. The names of those commenting on posts indicate a mix of Samaritan and non-Samaritan Arab followers. Most non-Samaritan family names indicate that they are probably from Nablus, e.g., al-Masri. In other words, this is a channel through which Samaritans (of the SLA) can communicate their aims and ideas to non-Samaritan Nabulsis. Events reported here are, on the one hand, religious festivals, but also, and mainly, exhibitions, workshops, and other activities organised by the SLA. There are pictures and comments about visitors to the Samaritan museum in Kiryat Luza, one of them obviously depicting a school class of Muslim girls. We find pictures of the regular exhibitions about Samaritan beliefs and culture at an-Najah National University in Nablus, as well as of a representative of the SLA visiting students of the local medical faculty to provide an introduction to Samaritanism, to name but a few.

Several posts refer to the tenth anniversary of the foundation of the SLA and the celebration that took place on that occasion in Kiryat Luza in July 2019. This celebration, headed by the slogan "Ten years of sacrifice and giving" (10 sanawat min al-'ata'), was a so-called "key event", when the workings of the public transcript could be observed in a very concentrated way. To begin with, the audience was of mixed religious affiliation. Not only Samaritans attended, but also Muslim and Christian invitees. The moderator, who led through the speeches and presentations, was a young Muslim woman resident of Kirzat Luza. Speakers included religious leaders, SLA members, politicians, and social players. Members of the SLA gave a short summary of the activities of the past ten years-including workshops, conferences, summer camps, and exhibitions in Palestine, Jordan, and later also Europe, as well as activities for Samaritan school children-pointing out that the first financial support for the SLA came in 2014 from the Bank of Palestine. The Vice Governor of Nablus explained, why the Samaritans are a symbol for Palestine's respect for plurality and diversity, and how important their role is in instilling this in the younger generations of Palestinians, regardless of religious affiliation. Very quickly, she turned in her speech towards the participation of the Samaritans in the political struggle for the freedom of Palestine and promised to fight for the liberation of Samaritan political prisoners in Israeli prisons. The secretary of the Christian-Muslim Council emphasised the similarities and holiness of Bible, Koran, and the Samaritan Torah. The Minister of Culture went even further to point out that the "true" owners of the land of Palestine were the Samaritans, Christians, and Muslims and that in each one of them there was a part of the others. He expressed thanks towards the SLA for familiarising non-Samaritan Palestinians with their (Palestinian) cultural and national identity, emphasising that they were celebrating not an insider-outsider relationship, or one between "Others", but one of "being the Other". In his words, there is no Palestine without Samaritans, or without Christians or Muslims, for that matter. Here, we already see an indication of one essential factor marking the public transcript of inter-religious relations in Nablus: "We are the owners of this land, regardless of religious affiliation", and, one may add, against an "enemy" that is trying to take this land. In other words, external forces help cement internal relations. The event ended with live music and dancing, the songs being a celebration of local identity and culture, another crucial aspect of the public transcript of inter-religious relations in Nablus.

On this occasion, one of the members of the SLA pointed to another function of the association apart from bringing their religion, history, and traditions closer to the non-Samaritan population of Nablus and elsewhere: to familiarise the young Samaritan generation with the details of their own religion. This statement would be in line with what Abdallah, the guide at the Samaritan museum, told me about the religious knowledge of young (and old) Samaritans, namely that, except for the clergy, they have very little detailed theological knowledge (even though most would fulfil important rituals), 
as there are no organised efforts to teach the young about their religion, in an equivalent perhaps of the Christian tradition of "Sunday schools". This aspect is of interest for the evaluation of the models of inter-religious competence, which generally assume that the development of inter-religious competence requires sound knowledge and understanding of one's own religious tradition. It appears that in the Nablus context, shared living can take place without deep knowledge of the religious tradition one was born into or calls one's own, despite an obviously clear positioning of those involved within this, their tradition. In other words, it is possible, even necessary, for Nabulsis to say "I am Samaritan/Christian/Muslim", without even having much insight into the respective precepts.

Another initiative equally quite lucidly illustrates the content of the public transcript on inter-religious relations in Nablus. Starting in July 2019, there have been several reports of a joint initiative, between the SLA, two Christian organisations ("Holy Book Association", "Christian Arab Scout Leaders"), a Muslim-Christian organisation, and a secular organisation ("Seeds for Development and Culture"), the first meeting of which was organised by the Prime Minister. The newspaper report on this initiative describes the position of those involved:

The representatives of the three "heavenly" religions (Islam, Christianity, Samaritanism) emphasised that Palestine in general represents a symbol not found elsewhere in the world, for a shared life between adherents of different religions, and that Nablus, in particular, is a model that embodies this life on the ground. In Nablus, Muslims live side by side with Christians and Samaritans in a climate of brotherhood, love, and mutual respect, with the desire of all to preserve this religious, historical, and cultural heritage (http://www.tmfm.net/article/65376; translation mine).

Similar to what I have pointed out earlier, the mayor of Nablus indicated in this meeting that what binds adherents of those three religions in Nablus together is their "love of the homeland (watan)" (ibid.). He even went so far as to say that, in this regard, Nablus represents a model "on the level of human societies in East and West" and that this "singular" situation has to be preserved (ibid.). The Chancellor, speaking on behalf of the Prime Minister, confirmed that the "heart of Nablus will remain open to all its sons and daughters regardless of their religious creed, that there is no difference between Muslim, Christian, and Samaritan, and that they are all joined in the melting pot of the struggle and of the loyalty towards the homeland" (ibid.). Similarly, an Orthodox priest emphasised that they were all joined "in pain and hope" under the roof of "one homeland called Palestine" (ibid.). The representative of the Dar al-Ifta' (Institution for Islamic legal advice) added that, while Muslims, Christians, and Samaritans were friends in Nablus, it is "the Occupation that is always trying to drive a wedge between us for its own benefits" (ibid.). Finally, a Samaritan priest explained that

Nablus is a symbol for shared life between different religions, [that] our homeland is Palestine, the cradle of religions, in which all societal ingredients are melted together, forming one of the oldest societies in the world. [ ... ] Despite the differences between our creeds (madhahibina) we are one people living in tolerance and mutual respect, appreciating the strong bonds that are built on solid sources: our aim is to live in a free, autonomous state (ibid.).

What emerges from events like these are several aspects marking inter-religious relations in Nablus. Firstly, such events and efforts to bring together representatives of the three religious communities in question are taking place regularly and frequently. This allows for at least two interpretations: it may indicate that mutual understanding between religious groups is great and something to be celebrated and confirmed at regular intervals; or it may point to an awareness that inter-religious cooperation is in fact endangered and has to be publicly emphasised in order not to be lost. Anecdotal evidence suggests that inter-religious peace and understanding has indeed been deteriorating over the past years, particularly with an increasing "Islamisation" of political (resistance) discourses. This does not only apply to Palestine, but to other countries of West Asia as well. This tendency is lucidly illustrated in the increasing use of the term "Muslim Palestine" (falastin al-muslima) (obviously meant 
to express opposition towards Israeli/Jewish policies) to describe the "homeland" on official occasions. It is obvious that religious minorities thereby feel excluded from the "homeland" and may want to make every effort to revert this tendency.

A second, related, aspect that becomes evident from such events is that it is particularly minority groups that have a keen interest in emphasising good neighbourly relations with the majority. Despite the fact that Muslim leaders are always present at such events and make similar statements to those of Christian or Samaritan representatives, they do not appear to be the driving forces behind them. The reports of the first meetings that eventually led to the event described above clearly show (in pictures and text as published, for instance, on the SLA Facebook page) that the initiative came from Christian and Samaritan organisations. Again, we may look at this as a reflection of the good relations that the minorities have with the majority, a celebration of harmony. Or it may be the result of existential fear of the minorities in the current climate of increasing fundamentalisms. The message of emphasising commonalities, harmony, and cooperation may be addressed towards the majority not to forget the historical heritage, not to forget minority contributions towards the political struggle, and, thus, not to be trampled upon. Conversations with minority students seem to make this interpretation quite likely.

A third aspect that emerges from these observations, already alluded to earlier, is that the political context is crucial for the shaping of inter-religious relations in Nablus. Representatives of all groups involved mention, in one form or another, that there is a "common enemy"-Israeli occupation-that binds them together in a shared struggle. It is reason and proof of the "brotherhood" of Samaritans, Christians, and Muslims in Nablus. My conversations with Nabulsis of all religious communities do indeed indicate that particularly the two intifadas have fostered an incredibly strong sense of local identity and loyalty. The rockets, tanks, or checkpoints did not differentiate according to religious affiliation. In times of curfew neighbours had to rely on each other, also across religious boundaries. There is a real sense of pride of having survived so many adversities, of being the cradle of the intifadas, of being a native of the "Mountain of Fire" (Jabal an-nar), as the region is called. This pride is sometimes even supported by a hadith (tradition) of a companion of the Prophet Muhammad saying: "The most beloved region by God is Greater Syria (ash-Sham); the most beloved part of Greater Syria is the Holy Land, and the most beloved part of the Holy Land is Nablus" (Al-Hanbali n.d., 75/2). Samaritans obviously have a similar, or even stronger, religious tie with the Nablus region through Mount Gerizim. In other words, we may assume that this strong sense local identity and "brotherhood" that has historical and, at least in parts, religious roots, but is reinforced by the current political context, is not just façade, but deeply felt by many or most inhabitants regardless of religious (or other) background.

It is these kinds of organisations, events, and narratives that are shaping the public transcript of inter-religious relations in Nablus. It would, however, be misleading to assume that this discourse is a one-to-one reflection of inter-religious relations on the ground. I have already alluded to the divergent interpretations that this discourse allows us. The social peace and the harmonious relations that are sung the praises of in public can only be maintained if there, simultaneously, is a space, where frictions, anger, or disappointments can be vented and expressed. Scott (1990) called this the "hidden transcript". In other words, if the public transcript features social harmony and cooperation, the hidden transcript—usually aired behind closed doors and out of earshot of the dominant or majority groups-is filled with gossip, stereotypes, stories of discrimination, and rhetorical reversals of social hierarchies. This does not mean that one transcript is "truer" than the other-they both represent sides of the same coin, which is society — but both enable the stability of existing social and power relations and the continuation of the status quo. The mere existence of a hidden transcript about the (religious) "Other", however, also indicates that certain issues are indeed "banned" from public discourse and relegated to hidden narratives in an effort to ensure "the peace". Discussing religious differences is the "stuff" of the hidden transcript, emphasising religious and other commonalities has its place in the public transcript. While the latter is certainly a marker of much inter-religious "dialogue" that is taking place in multifaith Europe-emphasising what binds us together-it is explicitly rejected in 
educational models of inter-religious competence, where one particular aim is to foster in learners a high level of tolerance of ambiguity and difference, i.e., to openly discuss differences and try to understand them rather than brushing them under the carpet.

\section{Conclusions}

Therefore, if we take the case study of Samaritans (and Christians) in Nablus as the background, against which models of inter-religious competence are tested, we have to conclude that the ability to solve problems of cross-cutting situations, of inter-religious coexistence-i.e., inter-religious competence-depends on many factors beyond religious knowledge and learning. If the overarching aim of acquiring inter-religious competence is to maintain stability and social peace, to acquire a "sense of the game" and play according to the rules, then the Samaritan case study of Nablus teaches us that there are various ways to achieve this aim and different elements of inter-religious competence that may signify in diverging contexts. What may work in one particular historical and/or cultural context, may fail in another. The cultural and religious context, in which most models of inter-religious competence have been developed is one where the majority of the population is of Christian or agnostic background, while large parts of the Muslim minority has a fairly recent migration background. Other religious groups taken into consideration here are also often associated with migration backgrounds. In the Nablus case study, not only are the proportions turned on their head-Muslims form the majority-but the minorities are also indigenous. In other words, they can, as communities, look back at historical experiences with each other and learn from them. They have already developed an inter-religious disposition of their habitus at a young age, which in the European context is generally little developed when children enter the education system. The Samaritans of Nablus seem to have developed strategies of avoidance as major and successful strategies of inter-religious competence. In Europe, first experiences of isolation and avoidance concerning migrating religious communities are now interpreted as "failure" to foster a sense of commonality or of shared identity. Shared identity-as Palestinians-is obviously something that, in contemporary times, members of the religious communities in Nablus emphasise frequently and, if my conversations with Nabulsis of diverging religious affiliations are any indication, do indeed feel. It may be that Samaritans, Christians, and Muslims in Nablus are an indication that the theoretical models developed for European educational settings are not universally valid as they claim.

Funding: This research received no external funding.

Conflicts of Interest: The authors declare no conflict of interest.

\section{References}

Al-Hanbali, Mujir ad-din. n.d. Al-Anas al-jalil fi al-quds wa al-khalil. Available online: https://web.archive.org/web/ 20170627083622/http://shamela.ws/browse.php/book-6626 (accessed on 20 November 2019).

Arif, Abdallah. 1964. Madinat Nablus. Dirasa iqlimiya (The city of Nablus. A sectional study). Unpublished Dissertation, University of Damascus, Damascus.

Austin, John L. 1962. How to do Things with Words. Cambridge: Harvard University Press.

Ayash, Adnan. 2003. Al-Ta'ifa al-samiriya fi Nablus. Dirasa fi mu'taqidatiha wa taqalidiha (The Samaritan community of Nablus. A study of their beliefs and practices). Nablus: Al-dar al-wataniya li-l-tarjama wa al-tiba'a wa al-nashr wa al-tawzi'.

Bernlocher, Max. 2013. Interkulturell-interreligiöse Kompetenz. Positionen und Perspektiven interreligiösen Lernens im Blick auf den Islam. Paderborn: Schöningh.

Bourdieu, Pierre. 1993. Sozialer Sinn. Kritik der theoretischen Vernunft. Frankfurt: Suhrkamp.

Bourdieu, Pierre. 2001. Die feinen Unterschiede. Kritik der gesellschaftlichen Urteilskraft. Frankfurt: Suhrkamp.

Dabbagh, Mustafa. 1947-1964. Biladna Falastin (Our Country Palestine). Yafa: Maktaba al-Taher.

Droeber, Julia. 2014. The Dynamics of Coexistence in the Middle East: Negotiating Boundaries between Christians, Samaritans, Jews and Muslims in Palestine. London: IB Tauris. 
Droeber, Julia. 2018. Von der Leiblichkeit interreligiöser Kompetenz im islamischen Religionsunterricht. Überlegungen zu den Bildungsplänen Baden-Württembergs. Theo-Web Zeitschrift für Religionspädagogik 17: 209-14.

Hecker, Simon. 2008. Dialog im Hamburger Religionsunterricht aus der Sicht muslimischer Schülerinnen und Schüler. Nordhausen: Traugott Bautz.

Heringer, Hans Jürgen. 2007. Interkulturelle Kommunikation. Tübingen: Francke.

Hitti, Philip. 1958. History of Syria, Lebanon, and Palestine. Arabic translation. Beirut: AUB Press.

Ibn al-'Ibri, Ahron. 1958. Tarikh mukhtasar ad-duwal, tahqiq al-ab Antun al-Yasu'i. Beirut, n.p. vol. 2, Available online: https://upload.wikimedia.org/wikisource/ar/2/21/\%D8\%AA\%D8\%A7\%D8\%B1\%D9\%8A\% D8\%AE_\%D8\%A7\%D8\%A8\%D9\%86_\%D8\%A7\%D9\%84\%D8\%B9\%D8\%A8\%D8\%B1\%D9\%8A.pdf (accessed on 4 February 2020).

Ireton, Sean. 2003. The Samaritans. A Jewish Sect in Israel. Unpublished MA dissertation, University of Kent, Canterbury, UK. Available online: http://www.anthrobase.com/Txt/I/Ireton_S_01.htm\#021_ Methodsandmaterials (accessed on 29 October 2019).

Kalbuna, Abdallah. 1992. Tarikh Madinat Nablus 2500 BCE-1918 CE (The History of Nablus). Nablus: n.p.

Kaufhold, Marisa. 2006. Kompetenz und Kompetenzerfassung. Analyse und Beurteilung von Verfahren der Kompetenzerfassung. Wiesbaden: VS Verlag.

Klieme, Eckhard, and Johannes Hartig. 2007. Kompetenzkonzepte in den Sozialwissenschaften und im erziehungswissenschaftlichen Diskurs. In Kompetenzdiagnostik. Berlin: Springer, pp. 11-29.

Kuld, Lothar, Friedrich Schweitzer, Werner Tzscheetzsch, and Joachim Weinhardt, eds. 2009. Im Religionsunterricht zusammenarbeiten. Evaluation des konfessionell-kooperativen Religionsunterrichts in Baden-Württemberg. Stuttgart: Kohlhammer.

Nimr, Ihsan. 1961. Ta'rikh Jabal al-Nar wa al-Balqa' (The history of the Nablus region and Balqa). Nablus: al-Nasr.

Pille, Thomas. 2002. Die Inkorporierung gesellschaftlicher Normen. Habitusirritationen als Beweggründe für das Tanzen in freien Formen. Unpublished dissertation. Available online: https://www.uni-oldenburg.de/fileadmin/user_upload/sport/download/soziologie/Pille_-_Die_ Inkorporierung_gesellschaftlicher_Normen_.pdf (accessed on 18 April 2019).

Pummer, Reinhard. 2016. The Samaritans. A Profile. Grand Rapids: Eerdmans.

Rabello, Alfredo Mordechai. 1997. The Samaritans in Justinian's Corpus Iuris Civilis. Israel Law Review 31: 724-43. [CrossRef]

Schur, Nathan. 1989. The modern period (from 1516 A.D.). In The Samaritans. Edited by Alan D. Crown. Tubingen: Mohr, pp. 113-34.

Schweitzer, Friedrich, Magda Bräuer, and Reinhold Boschki, eds. 2017. Interreligiöses Lernen durch Perspektivenübernahme. Münster: Waxmann.

Scott, James C. 1990. Domination and the Arts of Resistance. Hidden Transcripts. New Haven: Yale University Press.

Thomas, Alexander. 1993. „Psychologie interkulturellen Lernens und Handelns". In Kulturvergleichende Psychologie, Eine Einführung. Edited by Alexander Thomas. Göttingen: Hogrefe, pp. 433-86.

Thomas, Alexander. 2005. Grundlagen der interkulturellen Psychologie. Nordhausen: Traugott Bautz.

Tsedaka, Efrat. 2008. The Samaritans Walking Between the Israeli, Palestinian and Jordanian Raindrops. Available online: http://shomron0.tripod.com/articles/walkingbetween.pdf (accessed on 12 November 2019).

Weinert, Franz E. 2001. Vergleichende Leistungsmessung in Schulen - Eine umstrittene Selbstverständlichkeit. In Leistungsmessungen in Schulen. Edited by Franz E. Weinert. Weinheim: Beltz, pp. 17-31.

Willems, Joachim. 2011. Interreligiöse Kompetenz. Theoretische Grundlagen - Konzeptualisierungen Unterrichtsmethoden. Wiesbaden: VS Verlag.

(C) 2020 by the author. Licensee MDPI, Basel, Switzerland. This article is an open access article distributed under the terms and conditions of the Creative Commons Attribution (CC BY) license (http://creativecommons.org/licenses/by/4.0/). 